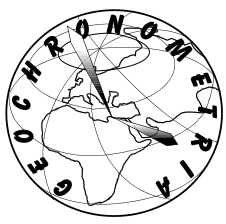

Conference Proceedings of the $12^{\text {th }}$ International Conference "Methods of Absolute Chronology" May 11-13 ${ }^{\text {th }}$ 2016, Gliwice-Paniówki, Poland

\title{
RADIOCARBON AND LEAD-210 AGE-DEPTH MODEL AND TRACE ELEMENTS CONCENTRATION IN THE WOLBROM FEN (S POLAND)
}

\author{
FATIMA PAWELCZYK ${ }^{1}$, LESZEK CHRÓST ${ }^{2}$, TADEUSZ MAGIERA ${ }^{3}$, ADAM MICHCZYŃSKI ${ }^{1}$, \\ JAROSŁAW SIKORSKI ${ }^{1}$, KONRAD TUDYKA ${ }^{1}$ and EWELINA ZAJĄC ${ }^{4}$ \\ ${ }^{1}$ Silesian University of Technology, Institute of Physics - Centre for Science and Education, Konarskiego 22B, 44-100 Gliwice, Poland \\ 2 "Ekopomiar" Ecological Laboratory, F. Chopina 26A/4, 44-100 Gliwice, Poland \\ ${ }^{3}$ Institute of Environmental Engineering, Polish Academy of Sciences, M. Sktodowskiej-Curie 34, 41-819 Zabrze, Poland \\ ${ }^{4}$ Faculty of Environmental Engineering and Land Surveying, University of Agriculture in Krakow, \\ Mickiewicza 21, 31-120 Krakow, Poland
}

Received 14 July 2016

Accepted 21 November 2016

\begin{abstract}
A one-meter long peat core was taken from the peatland in Wolbrom (Silesian-Cracovian Upland, southern Poland). The analysis of the botanical composition showed that Wolbrom is a fen. Vegetation species such as Carex rostrata and Phragmites australis have been found. An age-depth model was constructed using 12 conventional radiocarbon dates and 13 lead-210 dates from the upper part of the deposit. In this work, the results of radiocarbon dating are presented. According to the model, we can estimate the age of the fen. The oldest part comes from a depth of 1.05 meter and its conventional age is $5940 \pm 95 \mathrm{BP}$ (modelled date $5000-4790 \mathrm{BC}, 68.2 \%$ probability interval). The accumulation rate varies between approximately $0.53 \mathrm{~mm} \cdot \mathrm{yr}^{-1}$ and $6.48 \mathrm{~mm} \cdot \mathrm{yr}^{-1}$.

The core has been also tested for the presence of trace elements $(\mathrm{Co}, \mathrm{Cr}, \mathrm{Cu}, \mathrm{Fe}, \mathrm{Mn}, \mathrm{Ni}, \mathrm{Pb}, \mathrm{Zn})$ using ICP-OES. There are considerable variations in the concentrations of the tested metals - in many cases the concentration starts to rise at about $40 \mathrm{~cm}$ and may be connected with the human activity. This depth corresponds to the modelled age intervals 355-300 BC (17.4\%) and 205-45 BC (50.7\%).
\end{abstract}

Keywords: geochemical analysis, ${ }^{14} \mathrm{C}$ dating, ${ }^{210} \mathrm{~Pb}$ dating, peat pollution, peat sediments, southern Poland.

\section{INTRODUCTION}

It has been shown (Shotyk, 1996) that peat sediments are important archives for the reconstruction of the past environmental changes, induced naturally and by human activity. The Wolbrom fen has been investigated in the 1920's by Trela (1928). Paleobotanical studies were un-

Corresponding author: F. Pawełczyk e-mail: fatima.pawelczyk@polsl.pl dertaken again almost fifty years later by Latałowa (1976) and Obidowicz (1976) and once again in 1980's by Latałowa and Nalepka. The paleobotanical anlysis was supplemented by 19 radiocarbon dates, however the resolution of the dating was low and the dated samples were mostly taken from the depth below $1 \mathrm{~m}$ (Latałowa and Nalepka, 1987).

Trace elements have been introduced to the environment by the human activity since the very beginning of mining, coal combustion, smelting and metallurgy (Martínez Cortizas et al., 2016; Nriagu, 1996; De Vleeschouwer et al., 2007). The presence of trace ele- 
ments in the peat profile, e.g. lead and copper, which are supposed to be immobile in peat (Ali et al., 2008; MacKenzie et al., 1997; Vile et al., 1999) allows to trace and reconstruct the mining and metallurgical activity in the investigated area.

\section{SITE DESCRIPTION}

The fen in Wolbrom is located in the south of Poland, on the eastern part of Silesian-Cracovian Upland, in the Wolbrom Gate subregion (Kondracki, 2013). It is about $40 \mathrm{~km} \mathrm{~N}$ from Cracow (Fig. 1; 50 22,636' N, $19^{\circ}$ $\left.46,870^{\prime} \mathrm{E}\right)$. The fen is oblong, about $1000 \mathrm{~m}$ long and $500 \mathrm{~m}$ wide. The climate is moderate, with mean annual temperature of $c a .7^{\circ} \mathrm{C}$ and predominance of westerly winds. The average annual precipitation is about $700 \mathrm{~mm}$ (Kruczała, 2000). As the result of atmospheric fallout, soils in this area are enriched in potentially toxic elements, including $\mathrm{Pb}$ - the concentration is between 25 and $50 \mathrm{ppm}$ (see Lis and Pasieczna, 1995). The region suffers from deficiency of water. The drainage pattern is not very dense and the investigated fen is located on the watershed, between Szreniawa and Biała Przemsza rivers. In addition, this part of Silesian-Cracovian Upland is an area of Jurassic formations. It means that rain water accumulates in deep water-bearing strata (Nieć, 1997). A peat core was taken from the S-E part of the fen, from a different place than previously investigated.

\section{SAMPLING AND RESEARCH METHODS}

\section{Coring}

A peat core was taken using Wardenaar peat sampler. The taken core was $105 \mathrm{~cm}$ long with a cross section of $15 \mathrm{~cm} \times 15 \mathrm{~cm}$ (coordinates - see above). The upper $15 \mathrm{~cm}$ of the core was divided into $0.5 \mathrm{~cm}$ thick samples, the rest of the core was divided into $1 \mathrm{~cm}$ samples. After- wards the samples were dried at $70^{\circ} \mathrm{C}$. Subsequently, the samples for carbon-14 and lead-210 dating as well as for geochemical analysis were selected.

\section{Botanical analysis}

Four samples from every $25 \mathrm{~cm}$ of the peat core were taken for the analysis. The microscopic analysis of the botanical composition was conducted. On the base of it, the degree of decomposition and the type of peat were specified. In these analyses, standard methodology was used (see Maciak and Liwski, 1996; Maksimow, 1965; Myślińska, 2001; Tobolski, 2000). The botanical composition was specified by microscopic analysis, using comparative samples and literature (see Kac et al., 1977; Tobolski, 2000). First, the samples were washed on the $0.2 \mathrm{~mm}$ sieve in order to remove the humus substances. Afterwards every sample was divided into the three subsamples, which were analysed under microscope (100$400 \times$ zoom). Typological units of peat were defined on the base of genetic classification of Tolpa et al. (1967). The analyses were performed in the Faculty of Environmental Engineering and Land Surveying, in the University of Agriculture in Krakow.

\section{${ }^{14} \mathrm{C}$ dating}

Fifteen samples were selected for radiocarbon dating using liquid scintillation counting technique. In order to remove carbonates the samples were treated with a $2 \%$ $\mathrm{HCl}$ solution at $80^{\circ} \mathrm{C}$ for 1 hour as standard procedure i.e. Acid-Alkali-Acid would dissolve the samples. After the pretreatment, samples were rinsed with deionized water and dried. Next, samples were converted to benzene in a vacuum line (Skripkin and Kovaliukh, 1998). The scintillation cocktails were prepared by adding $13 \mathrm{mg}$ of butylPBD per $1 \mathrm{ml}$ of benzene. ${ }^{14} \mathrm{C}$ measurements were performed on two Quantulus 1220 and two ICELS (Theodórsson, 2005) systems. Quantulus 1220 spectrometers

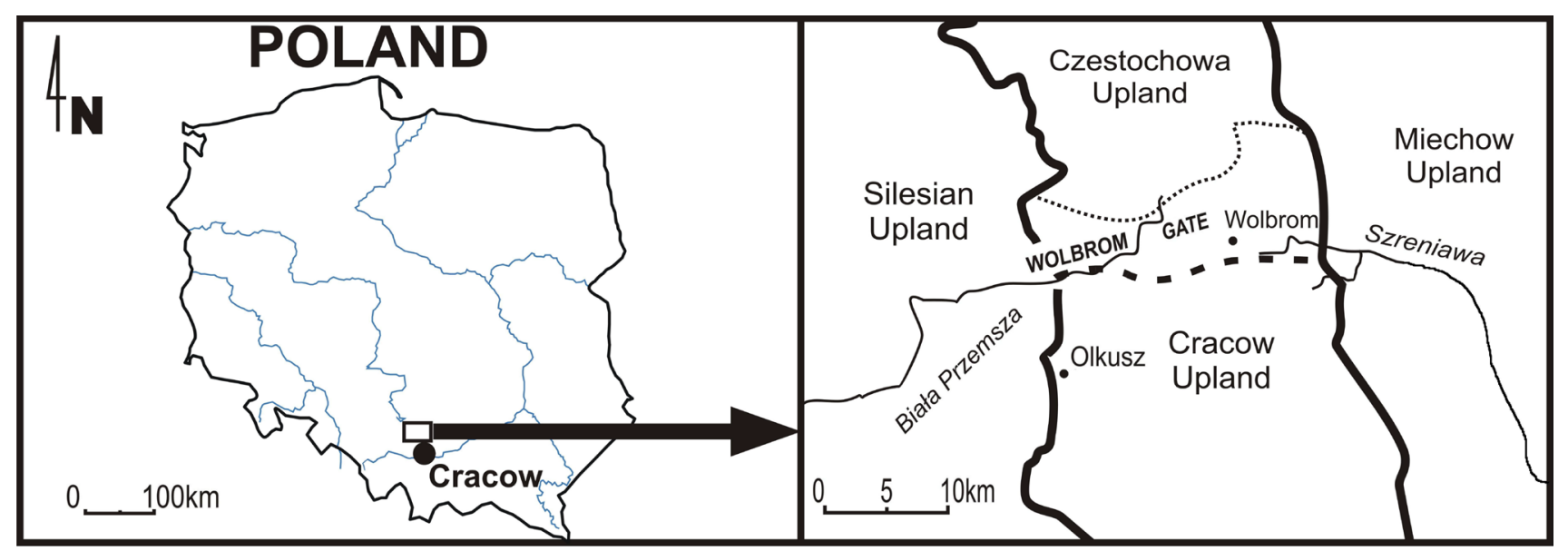

Fig. 1. Location of the Wolbrom fen. 
were set-up and calibrated according to Pawlyta et al. (1998). The ICELS systems were measuring ${ }^{14} \mathrm{C}$ in the fixed energy balance counting mode (Tudyka and Pazdur, 2012) with simultaneous ${ }^{214} \mathrm{Bi} /{ }^{214}$ Po pairs counting for routine ${ }^{222} \mathrm{Rn}$ contamination correction (Tudyka et al., 2015). Four LSC spectrometers allowed to reduce the possible systematic error. Radiocarbon dating was performed in the Gliwice Radiocarbon Laboratory.

\section{${ }^{210} \mathrm{~Pb}$ dating}

The samples were subjected to the chemical preparation in order to obtain sources for the measurement of alpha activity of ${ }^{210} \mathrm{~Pb}$ (see Sikorski and Bluszcz, 2003, 2008). After drying, the 14 samples were treated with a hot $65 \%$ nitric acid $\left(90^{\circ} \mathrm{C}\right.$ for 3 hours). Afterwards, the solution was centrifuged (5000 rpm, $10 \mathrm{~min})$. Liquid solution was collected and treated with $30 \mathrm{ml}$ of $30 \%$ $\mathrm{H}_{2} \mathrm{O}_{2}$ (to oxidise organic matter). After evaporation to dryness, every sample was treated with $35-38 \%$ hydrochloric acid and evaporated again. This step was repeated a few times in order to fully replace nitric acid by hydrochloric acid. Afterwards, polonium was deposited on a silver disc from $75 \mathrm{ml}$ of a $0.5 \mathrm{M}$ solution of hydrochloric acid, with addition of $0.4 \mathrm{~g}$ of hydroxyloamine and $0.4 \mathrm{~g}$ of sodium citrate, at $90^{\circ} \mathrm{C}$. The radioactivity of polonium was measured using an alpha spectrometer (Canberra model 7401) with Passivated Implanted Planar Silicon (PIPS) Detector. The sensitive area of the detector was $300 \mathrm{~mm}^{2}$ and its energy resolution was ca. $20 \mathrm{keV}$. The preparation and the measurement were performed at the Gliwice Radioactivity Measurements Laboratory. Results of measurements of ${ }^{210} \mathrm{~Pb}$ concentration in the core and calculated ${ }^{210} \mathrm{~Pb}$ dates are presented in Fig. 2.

\section{Geochemical analysis}

The 54 analysed samples were homogenized, dried and then ground in an agate mortar. Samples prepared in this way were then heated to a temperature of $200^{\circ} \mathrm{C}$ for one hour to initially carbonize the organic matter and subsequently incinerated at a temperature of $450^{\circ} \mathrm{C}$ for four hours before being extracted using concentrated nitric acid. After evaporation to dryness in a water bath, the samples were combusted at $450^{\circ} \mathrm{C}$ for one hour and then treated with a hydrochloric acid solution $(1: 1)$ to remove carbonates (Karczewska and Kabała, 2008). Determination of the metals was carried out by means of Inductively Coupled Plasma Optical Emission Spectroscopy techniques at the Laboratory of the Institute of Environmental Engineering of Polish Academy of Sciences in Zabrze. The measurement uncertainties were estimated in accordance with the recommendations received from the laboratory and they are appropriate for the analysis of peat.
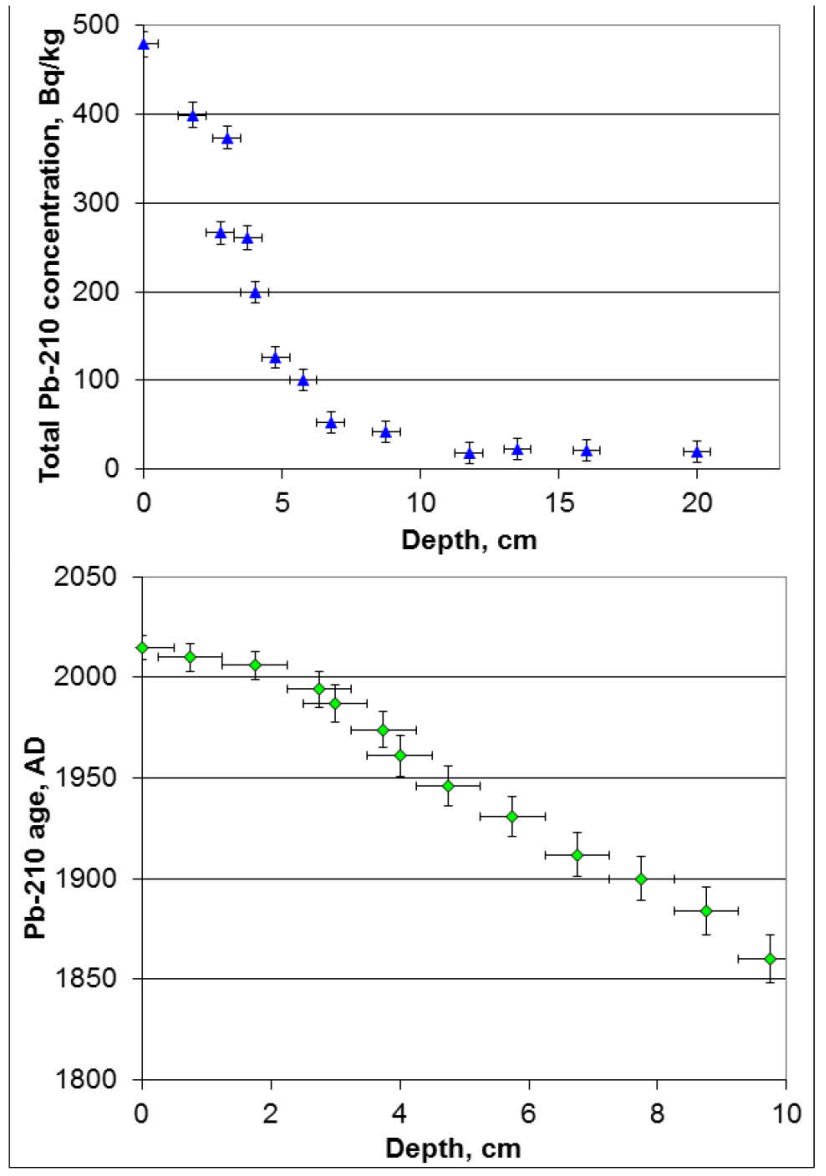

Fig. 2. Results of measurements of $210 \mathrm{~Pb}$ concentration in the core W3 and calculated $210 \mathrm{~Pb}$ dates.

\section{RESULTS}

The botanical analysis showed that numerous remains of Carex and Phragmites were found. The peat was specified as highly decomposed in the upper part of the core and poorly decomposed in the lower part (Table 1). Because of its botanical composition the study area can be considered to be a fen (Tobolski, 2000).

Obtained results of radiocarbon measurements are presented in Table 2. All the results were calibrated using OxCal v4.2.4. (Bronk Ramsey and Lee, 2013) calibration program with application of IntCal13 (Reimer et al., 2013) and Bomb13 NH1 calibration curves. The table presents also intervals of modelled age calculated basing on an age-depth model described below.

At the beginning of analysing the results of radiocarbon dating we noticed that the sample from the depth $34-35 \mathrm{~cm}$ (sample W3 34-35, GdS-3132) is much younger than other samples from the neighboring context. We 
Table 1. Results of botanical analysis.

\begin{tabular}{|c|c|c|c|c|}
\hline $\begin{array}{l}\text { Depth } \\
(\mathrm{m})\end{array}$ & $\begin{array}{l}\text { Botanical composition } \\
\text { Species }\end{array}$ & $(\%)$ & Peat type & $\begin{array}{l}\mathrm{D} \\
(\%) \\
\end{array}$ \\
\hline $0.00-0.25$ & - & - & Saprists & $>60$ \\
\hline \multirow{8}{*}{$0.25-0.50$} & Carex rostrata & & \multirow{8}{*}{$\begin{array}{l}\text { Cariceto- } \\
\text { Phragmiteti }\end{array}$} & \multirow{8}{*}{55} \\
\hline & Carex hudsoni ? & 50 & & \\
\hline & Carex appropinquata & 50 & & \\
\hline & Carex sp.div. & & & \\
\hline & Phragmites australis & 35 & & \\
\hline & Calamagrostis neglecta & 5 & & \\
\hline & Typha angustifolia et latifolia & + & & \\
\hline & Unmarked & 10 & & \\
\hline \multirow{10}{*}{$0.50-0.75$} & Carex rostrata & \multirow{4}{*}{45} & \multirow{10}{*}{$\begin{array}{c}\text { Bryalo- } \\
\text { Parvocaricioni }\end{array}$} & \multirow{10}{*}{40} \\
\hline & Carex gracilis & & & \\
\hline & Carex nigra & & & \\
\hline & Carex sp. div. & & & \\
\hline & Phragmites australis & 5 & & \\
\hline & Menyanthes trifoliata & 10 & & \\
\hline & Equisetum sp. & + & & \\
\hline & Bryales sp. div. & 30 & & \\
\hline & Unmarked & 10 & & \\
\hline & $\begin{array}{l}\text { Gaeumannomyces } \\
\text { cf. caricis? }\end{array}$ & + & & \\
\hline \multirow{11}{*}{$0.75-1.00$} & Carex appropinquata & \multirow{6}{*}{-50} & \multirow{11}{*}{ Magnocaricioni } & \multirow{11}{*}{35} \\
\hline & Carex pseudocyperus & & & \\
\hline & Carex rostrata & & & \\
\hline & Carex lasiocarpa & & & \\
\hline & Carex riparia & & & \\
\hline & Carex sp. & & & \\
\hline & Phragmites australis & 15 & & \\
\hline & Calamagrostis neglecta & 5 & & \\
\hline & Equisetum (limosum?) & + & & \\
\hline & Bryales sp. & 20 & & \\
\hline & Unmarked & 10 & & \\
\hline
\end{tabular}

decided to reject this result from the further analysis assuming that the sample could be contaminated by younger organic material in situ (roots of present plants) or during collecting process. Therefore, we started the construction of the age-depth model from the analysis of 14 radiocarbon dates from depths from $4.5-5 \mathrm{~cm}$ to 104 $105 \mathrm{~cm}$ and $12{ }^{210} \mathrm{~Pb}$ dates appointed for the upper $10 \mathrm{~cm}$ of the sediment (see Fig. 2, without the date for $0 \mathrm{~cm}$ depth).

The chronology of this upper $10 \mathrm{~cm}$ of sediment is very well defined by twelve ${ }^{210} \mathrm{~Pb}$ dates and covers a time range since $1860 \pm 12 \mathrm{AD}$ (depth $9.75 \mathrm{~cm}$ ) till now (date $2010 \pm 7 \mathrm{AD}$ at depth $0.75 \mathrm{~cm}$ ). In good correspondence with this chronology is the radiocarbon date for a sample from the depth 4.5-5 cm (sample W3 4,5-5, GdS-3147). This date, after calibration using Bomb13 NH1 calibration curve gives two possible calendar dates - the first, the most probable result - an interval since 2004 AD till now and the second, pointing to year 1957 AD (see Table 2). This second option perfectly agrees with the lead date for the depth $4.75 \mathrm{~cm}$, which is $1946 \pm 10 \mathrm{AD}$.
The first radiocarbon date below the ${ }^{210} \mathrm{~Pb}$ chronology (W3 9,5-10, GdS-3212) is much older than the last date of this chronology and has radiocarbon age equal $1630 \pm 65 \mathrm{BP}$ (after calibration 95.4\% interval is approx. 250-570 AD). Also, the next five samples from depths between $13 \mathrm{~cm}$ and $30 \mathrm{~cm}$ have been dated for calendar ages from a range 200-800 AD. It clearly shows that there is a hiatus in the core at about $10 \mathrm{~cm}$. The cause of this hiatus may be an extraction of peat at the investigated fen. The group of dates directly below the hiatus (depths $10-30 \mathrm{~cm}$ ) constitutes the most difficult to interpretation part of the chronology of the core. The radiocarbon dates have similar values and these, which occur near the hiatus, are not in stratigraphic order. It may mean that some part of sediment from depths $10-30 \mathrm{~cm}$ could be mixed during excavation, but structure of the sediment does not suggest if and which part is mixed. Therefore, we assumed that mixed part of sediment may occur only in a strict neighborhood of the hiatus level. Because radiocarbon dates of samples W3 9.5-10 (GdS-3212) and W3 1313.5 (GdS-3261), which come from this unclear context, are older than dates of samples from depth below we decided to remove these results for our age-depth model. We assumed also that the part of sediment from depths below $13 \mathrm{~cm}$ is in stratigraphic order. The results of radiocarbon dating for samples from depths below $30 \mathrm{~cm}$ to the end of core $(105 \mathrm{~cm})$ clearly shows stratigraphic chronology of this part of the sediment.

Finally, the proposed age-depth model is constructed on the basis of $12{ }^{14} \mathrm{C}$ dates and $13{ }^{210} \mathrm{~Pb}$ dates using OxCal v4.2.4. (Bronk Ramsey and Lee, 2013) calibration program. The construction was performed with a use of two PSequence commands separated by Interval command, which include information about hiatus to the model. For the $k$ parameter values 0.5 (PSequence for a part below hiatus) and 1 (PSequence for a part above hiatus) were chosen. Total agreement index of the model amounts to $53.6 \%$, which is a little below suggested value $60 \%$ but may be accepted, especially that it is caused only by the radiocarbon date of sample W3 4,5-5 which agrees with the ${ }^{210} \mathrm{~Pb}$ dates. The age-depth model is presented in Fig. 3.

The geochemical analysis, made with the resolution of 1-3 cm, showed the variability of trace elements $(\mathrm{Co}$, $\mathrm{Cr}, \mathrm{Cu}, \mathrm{Fe}, \mathrm{Mn}, \mathrm{Ni}, \mathrm{Pb}$ and $\mathrm{Zn}$ ) concentrations in the peat profile (Fig. 4). At a depth of $45 \mathrm{~cm}$, which corresponds to age interval $1270-1045 \mathrm{BC}$, the concentration of zinc and cobalt increases rapidly up to the maximum at 12 $15 \mathrm{~cm}$, which corresponds to the age interval 610-665 AD (68.2\% probability, in accordance with an age-depth model). Also, the concentration of lead and copper starts to increase at a depth of approximately $45 \mathrm{~cm}$ but lead has its maximum at $6 \mathrm{~cm}$ depth and copper almost at the ground level (at $1.75 \mathrm{~cm}$ depth). A visible correlation between some pairs of metals, such as $\mathrm{Cr}-\mathrm{Ni}$ and $\mathrm{Co}-\mathrm{Mn}$ were found. The concentration of trace elements was also shown in the time scale, based on the age-depth model 
Table 2. Results of radiocarbon dating of samples from Wolbrom site, W3 core.

\begin{tabular}{|c|c|c|c|c|c|c|}
\hline $\begin{array}{l}\text { Lab } \\
\text { code }\end{array}$ & $\begin{array}{l}\text { Depth } \\
\text { (cm) }\end{array}$ & $\begin{array}{l}\text { Conventional }{ }^{14} \mathrm{C} \\
\text { age/radioactivity } \\
\text { (BP / pMC) }\end{array}$ & $\begin{array}{c}\text { Calibrated age range } \\
68.2 \% \\
\text { (cal BC/AD) }\end{array}$ & $\begin{array}{c}\text { Calibrated age range } \\
95.4 \% \\
\text { (cal BC/AD) }\end{array}$ & $\begin{array}{l}\text { Modelled age range } \\
68.2 \% \text { (cal BC/AD) }\end{array}$ & $\begin{array}{l}\text { Modelled age range } \\
95.4 \% \text { (cal BC/AD) }\end{array}$ \\
\hline $\begin{array}{l}\text { GdS- } \\
3147\end{array}$ & $4.5-5$ & $105.5 \pm 0.70 \mathrm{pMC}$ & $2006-2013$ AD & $\begin{array}{c}1956-1957 \text { AD }(0.6 \%) \\
2004-2013 \text { AD }(94.8 \%)\end{array}$ & 1955-1960 AD & $1955-1960$ AD \\
\hline $\begin{array}{l}\text { GdS- } \\
3212\end{array}$ & $9.5-10$ & $1630 \pm 65 \mathrm{BP}$ & $\begin{array}{l}345-370 \text { AD ( } 8.0 \%) \\
375-475 \text { AD }(39.3 \%) \\
485-535 \text { AD }(21.0 \%) \\
\end{array}$ & $\begin{array}{c}250-305(7.0 \%) \\
310-570 \text { AD }(88.4 \%)\end{array}$ & not included in the model & not included in the model \\
\hline $\begin{array}{l}\text { GdS- } \\
3261\end{array}$ & $13-13.5$ & $1615 \pm 90 \mathrm{BP}$ & $340-545 \mathrm{AD}$ & $235-625$ AD & not included in the model & not included in the model \\
\hline $\begin{array}{l}\text { GdS- } \\
3130\end{array}$ & $14.5-15$ & $1420 \pm 50 \mathrm{BP}$ & $590-660$ AD & $540-685$ AD & $610-665$ AD & $\begin{array}{c}565-690 \text { AD }(93.7 \%) \\
745-765(1.7 \%)\end{array}$ \\
\hline $\begin{array}{l}\text { GdS- } \\
3213\end{array}$ & $19-20$ & $1540 \pm 90 \mathrm{BP}$ & $420-600$ AD & $330-660$ AD & $515-615$ AD & $470-645 \mathrm{AD}$ \\
\hline $\begin{array}{l}\text { GdC- } \\
1122\end{array}$ & $24-25$ & $1410 \pm 70 \mathrm{BP}$ & 565-675 AD & $\begin{array}{c}430-490 \text { AD }(4.9 \%) \\
530-730 \mathrm{AD}(86.3 \%) \\
735-770 \mathrm{AD}(4.2 \%)\end{array}$ & $\begin{array}{c}425-495 \text { AD }(60.5 \%) \\
540-560 \text { AD }(7.7 \%)\end{array}$ & $415-595$ AD \\
\hline $\begin{array}{l}\text { GdS- } \\
1976\end{array}$ & $29-30$ & $1635 \pm 95 \mathrm{BP}$ & $\begin{array}{c}260-275 \text { AD }(2.2 \%) \\
330-540 \text { AD }(66.0 \%)\end{array}$ & $\begin{array}{c}170-195 \text { AD }(1.1 \%) \\
210-620 \text { AD }(94.3 \%)\end{array}$ & $\begin{array}{l}255-305 \text { AD }(19.5 \%) \\
315-420 \text { AD }(48.7 \%)\end{array}$ & $165-495$ AD \\
\hline $\begin{array}{l}\text { GdS- } \\
3132\end{array}$ & $34-35$ & $1095 \pm 35 \mathrm{BP}$ & $\begin{array}{l}\text { 895-930 AD (26.5\%) } \\
940-990 \mathrm{AD}(41.7 \%)\end{array}$ & 880-1020 AD & not included in the model & not included in the model \\
\hline $\begin{array}{l}\text { GdS- } \\
1987\end{array}$ & $39-40$ & $2040 \pm 85 \mathrm{BP}$ & $\begin{array}{c}170 \mathrm{BC}-30 \mathrm{AD}(64.7 \%) \\
35-55 \mathrm{AD}(3.5 \%)\end{array}$ & $\begin{array}{c}360-285 \mathrm{BC}(5.7 \%) \\
235 \mathrm{BC}-135 \mathrm{AD}(89.7 \%)\end{array}$ & $\begin{array}{c}355-300 \mathrm{BC}(17.4 \%) \\
205-45 \mathrm{BC}(50.7 \%)\end{array}$ & $370 \mathrm{BC}-30 \mathrm{AD}$ \\
\hline $\begin{array}{l}\text { GdS- } \\
3279\end{array}$ & $44-45$ & $2960 \pm 75 \mathrm{BP}$ & $1275-1050 \mathrm{BC}$ & $1400-975 \mathrm{BC}$ & $1270-1045$ BC & $\begin{array}{c}1395-975 \text { BC }(94.8 \%) \\
955-940 \text { BC }(0.6 \%)\end{array}$ \\
\hline $\begin{array}{l}\text { GdC- } \\
1120\end{array}$ & $54-55$ & $4480 \pm 85 \mathrm{BP}$ & $\begin{array}{c}3340-3085 \text { BC }(62.2 \%) \\
3060-3030 \text { BC }(6.0 \%)\end{array}$ & $\begin{array}{c}3485-3475 \text { BC }(0.2 \%) \\
3370-2915 \text { BC }(95.2 \%)\end{array}$ & $3125-2915 \mathrm{BC}$ & $3270-2895$ BC \\
\hline $\begin{array}{l}\text { GdS- } \\
3280\end{array}$ & $64-65$ & $4790 \pm 85 \mathrm{BP}$ & $\begin{array}{l}3655-3510 \text { BC }(57.5 \%) \\
3425-3380 \text { BC }(10.7 \%)\end{array}$ & $\begin{array}{c}3750-3740 \text { BC }(0.2 \%) \\
3715-3365 \text { BC }(95.2 \%)\end{array}$ & $\begin{array}{l}3645-3505 \text { BC }(56.1 \%) \\
3425-3380 \text { BC }(12.0 \%)\end{array}$ & $\begin{array}{l}3695-3480 \text { BC }(69.5 \%) \\
3475-3370 \text { BC }(25.8 \%)\end{array}$ \\
\hline $\begin{array}{l}\text { GdS- } \\
3281\end{array}$ & $79-80$ & $5385 \pm 95 \mathrm{BP}$ & $\begin{array}{l}4340-4220 \text { BC }(37.7 \%) \\
4210-4155 \text { BC }(13.9 \%) \\
4135-4070 \text { BC }(16.6 \%)\end{array}$ & $\begin{array}{c}4445-4420 \text { BC }(1.1 \%) \\
4375-3985 \text { BC }(94.3 \%)\end{array}$ & $\begin{array}{c}4250-4230 \text { BC }(4.1 \%) \\
4210-4040 \text { BC }(64.1 \%)\end{array}$ & $4320-3985 \mathrm{BC}$ \\
\hline $\begin{array}{l}\text { GdC- } \\
1121\end{array}$ & $94-95$ & $5715 \pm 70 \mathrm{BP}$ & $\begin{array}{c}4670-4635 \text { BC }(8.1 \%) \\
4620-4460 \text { BC }(60.0 \%)\end{array}$ & $\begin{array}{c}7720-4440 \text { BC }(91.6 \%) \\
4425-4370 \text { BC }(3.8 \%)\end{array}$ & $\begin{array}{l}4670-4630 \text { BC }(12.7 \%) \\
4620-4495 \text { BC }(55.5 \%)\end{array}$ & $4720-4450 \mathrm{BC}$ \\
\hline $\begin{array}{l}\text { GdS- } \\
3148\end{array}$ & 104-105 & $5940 \pm 95 \mathrm{BP}$ & $4945-4710 \mathrm{BC}$ & $5060-4550 \mathrm{BC}$ & $5000-4790 \mathrm{BC}$ & $\begin{array}{c}5210-5160 \text { BC }(2.7 \%) \\
5120-5105 \text { BC }(0.4 \%) \\
5080-4700 \text { BC }(92.3 \%)\end{array}$ \\
\hline
\end{tabular}

(Fig. 5). The Fe/Mn ratio (Fig. 6) displays considerable variations (Boyle, 2001). It has its minimum values between $4900 \mathrm{BC}$ and $3045 \mathrm{BC}$ as well as between $1165 \mathrm{BC}$ and $640 \mathrm{AD}$. The highest values of $\mathrm{Fe} / \mathrm{Mn}$ ratio occurs in the upper part of the core. There is also visible high value of $\mathrm{Fe} / \mathrm{Mn}$ ratio between 3045 and $1165 \mathrm{BC}$ (median age, in accordance with an age-depth model).

\section{DISCUSSION AND CONCLUSIONS}

An analysis connected with construction of the agedepth model shows that a precision of a time scale constructed for the investigated core is different for different fragments of the sediment. The most precise and reliable is a part based on lead dates (depth above $10 \mathrm{~cm}$ ) and a part based on radiocarbon dates for depths below $30 \mathrm{~cm}$. On the other hand, there are some doubts concerning a fragment of core between $10 \mathrm{~cm}$ and $30 \mathrm{~cm}$ depth. The occurrence of the hiatus seems to be indisputable. However, a part between $10 \mathrm{~cm}$ and about $13 \mathrm{~cm}$ is based only on an estimation of a trend of the age-depth model for depths below $13 \mathrm{~cm}$, so it is not precise. The time scale for a part between $13 \mathrm{~cm}$ and $30 \mathrm{~cm}$ depth is much more precise and reliable than this for depths $10-13 \mathrm{~cm}$, but is based on an assumption that this part of the sediment is in stratigraphic order. We considered also another hypothesis (mixing of the sediment, an aging of the sediment because of a kind of reservoir effect), but at this moment we have not found strong evidence to support this hypothesis, whereas the assumption concerning the stratigraphic order is supported by a good value of the agreement index of our age-depth model.

It is noteworthy that the peat is very compressed. The mean accumulation rate varies between $0.53 \mathrm{~mm} \cdot \mathrm{yr}^{-1}$ and $6.48 \mathrm{~mm} \cdot \mathrm{yr}^{-1}$. According to the age-depth model, the mean accumulation rate depends on the period on the time scale (see Fig. 3). The highest accumulation rate occurs in the upper part of the profile (from approximately $10 \mathrm{~cm}$ depth to the top which corresponds with last 200 years (according to ${ }^{210} \mathrm{~Pb}$ dates). Next, the mean 


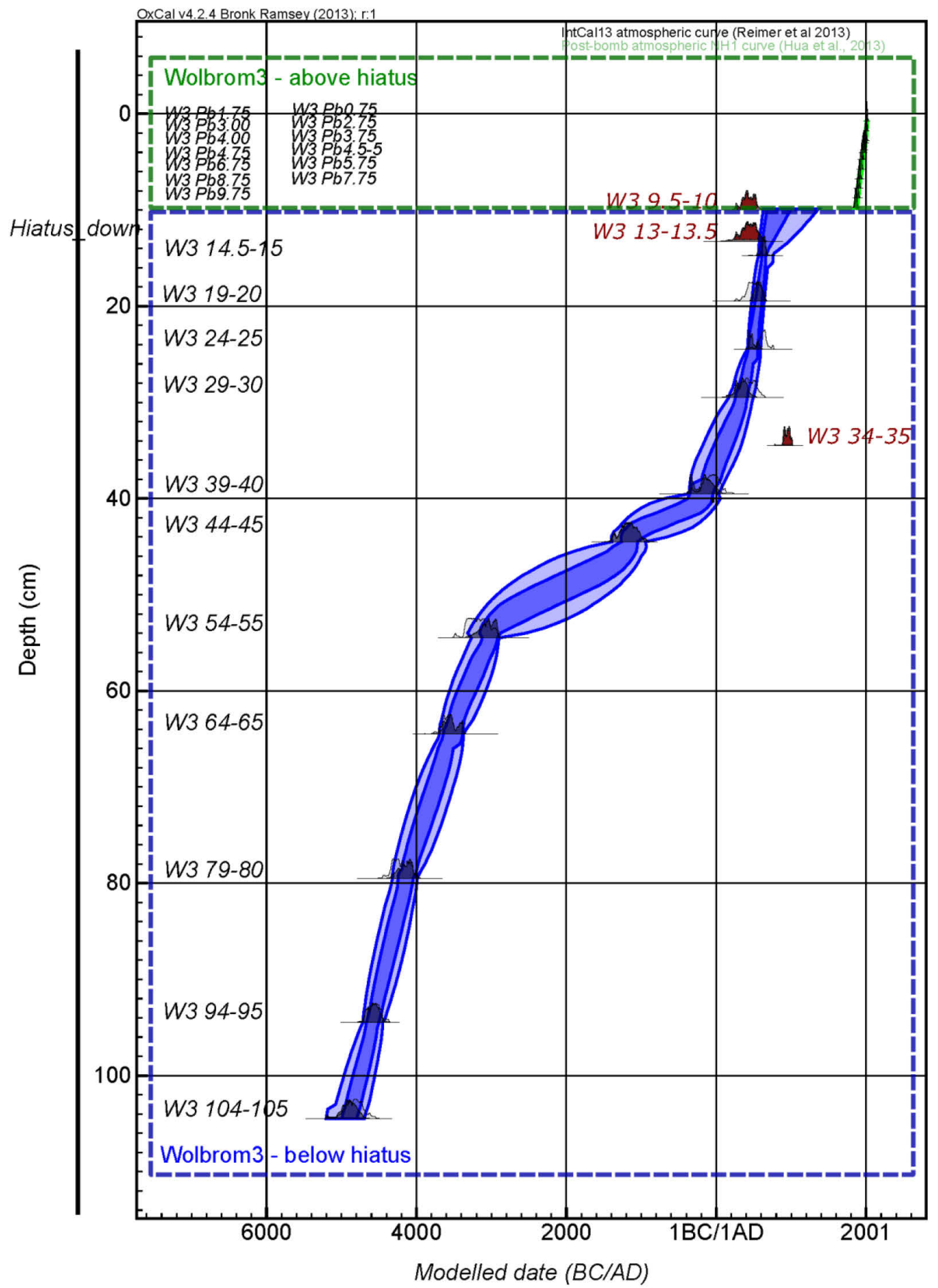

Fig. 3. Age-depth model for Wolbrom W3 core. Radiocarbon dates which are not included to the model are presented in red.

accumulation rate slows down, and reach its minimum between approx. $155 \mathrm{BC}$ (depth $40 \mathrm{~cm}$ ) and $3045 \mathrm{BC}$ (depth $55 \mathrm{~cm}$ ). It can be connected with some environmental and/or climate changes, like water table changes Before approximately $3045 \mathrm{BC}$ the mean accumulation rate is higher again and similar to this, which occur after $155 \mathrm{BC}$.

The concentration of trace elements is comparable or lower than in other locations in southern Poland (ŚmiejaKról et al., 2015). However, the concentration of $\mathrm{Pb}$ and 


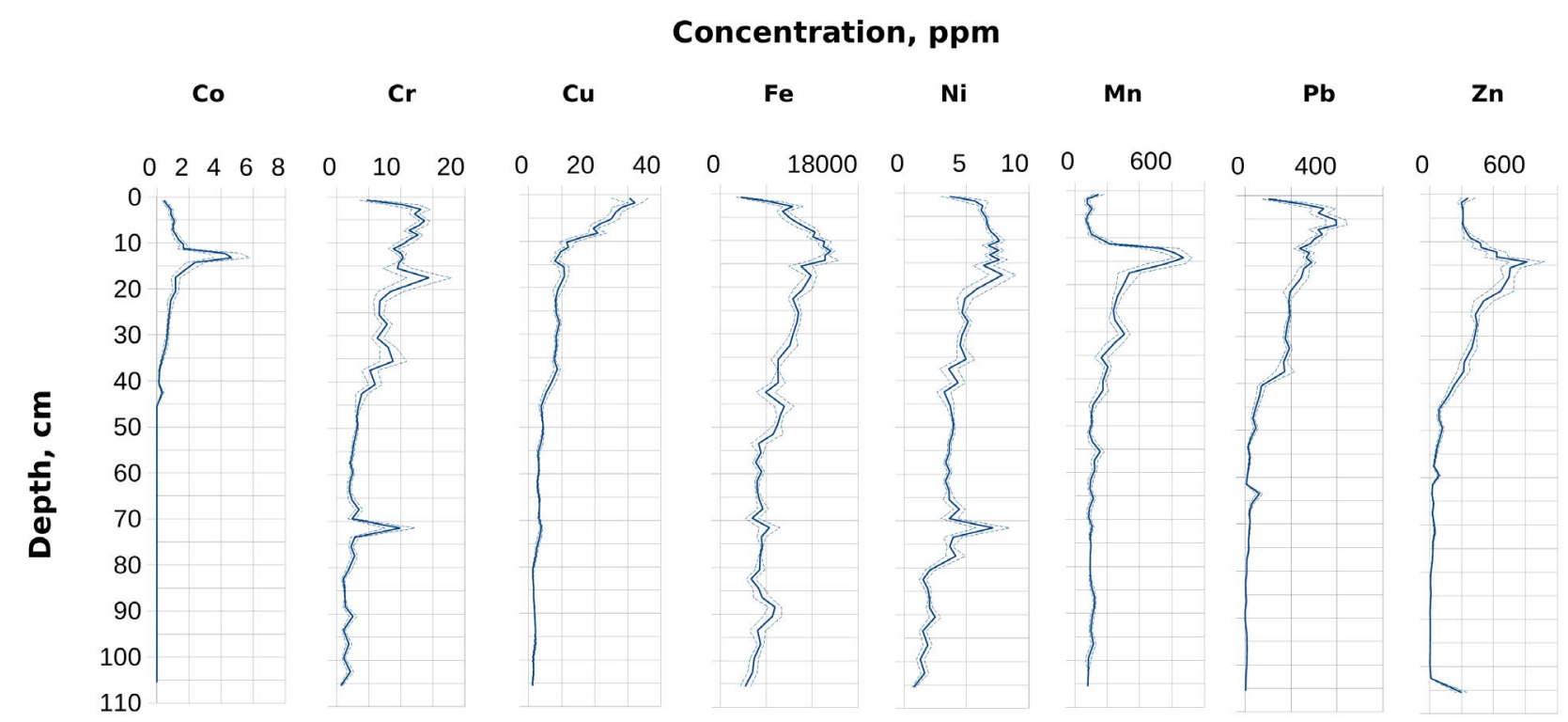

Fig. 4. Concentrations of major and trace elements as a function of depth.

\section{Concentration, ppm}

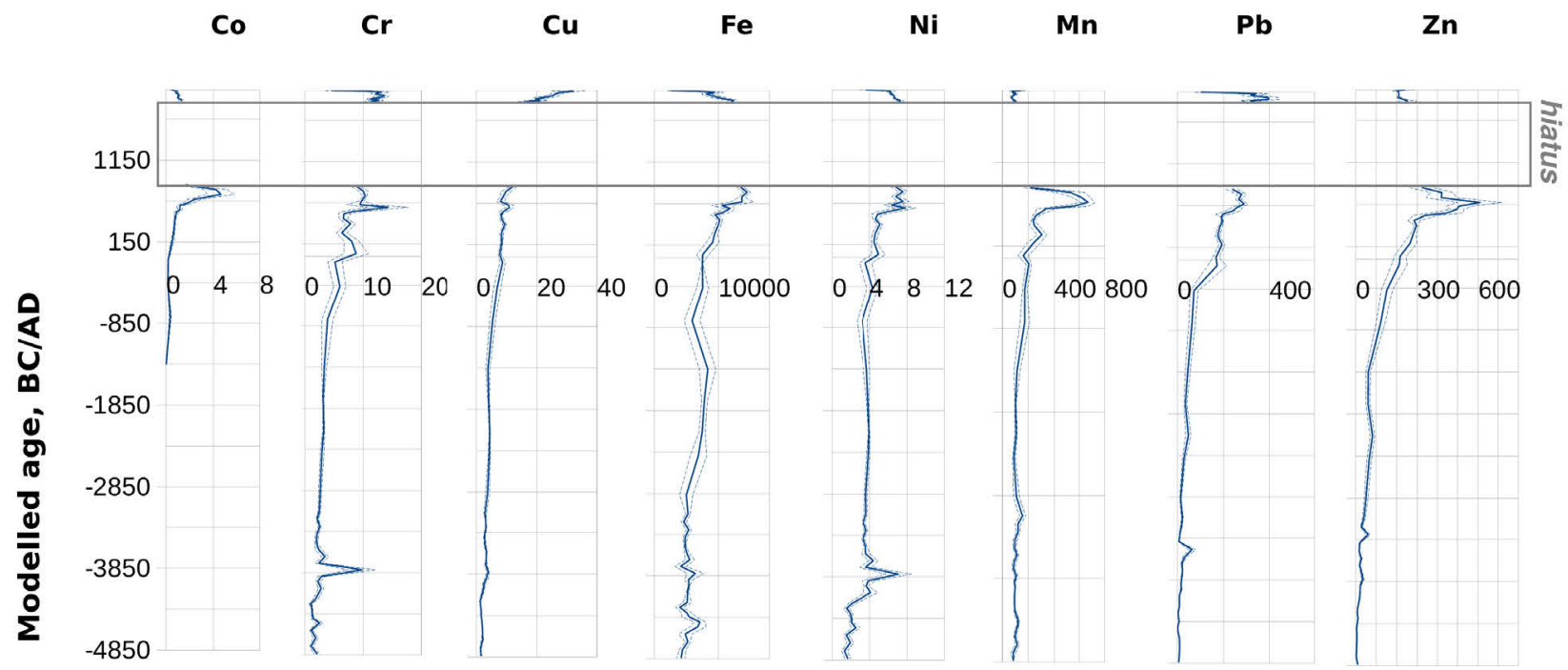

Fig. 5. Concentrations of major and trace elements as a function of age.

$\mathrm{Zn}$ is much higher than mean values for peatlands in Poland. The maximum concentration of $\mathrm{Zn}$ in Wolbrom fen is $609 \mathrm{ppm}$ and the mean concentration value for Poland is $31 \mathrm{ppm}$. The maximum concentration of lead in Wolbrom is more than 400 ppm, while the mean concentration of lead for peatlands in Poland is $12 \mathrm{ppm}$ (Bojakowska and Lech, 2008; Ilnicki, 2002). The highest values of $\mathrm{Fe} / \mathrm{Mn}$ ratio in the upper part of the core may be related to intensified oxidation of Fe just below the sedi- ment surface. The high value of Fe/Mn ratio between 40 and $55 \mathrm{~cm}$ depth corresponds to the lower accumulation rate. It is clearly visible on the age-depth model (from $3045 \mathrm{BC}$ to $155 \mathrm{BC}$ - median age) and may indicate higher water table in that period (Pawłowski et al., 2015, 2016).

Increase of the trace elements concentration shown in Fig. 4 and 5 can be related with the human activity such as mining and metallurgy. West of Wolbrom there is a 


\section{Fe/Mn ratio}

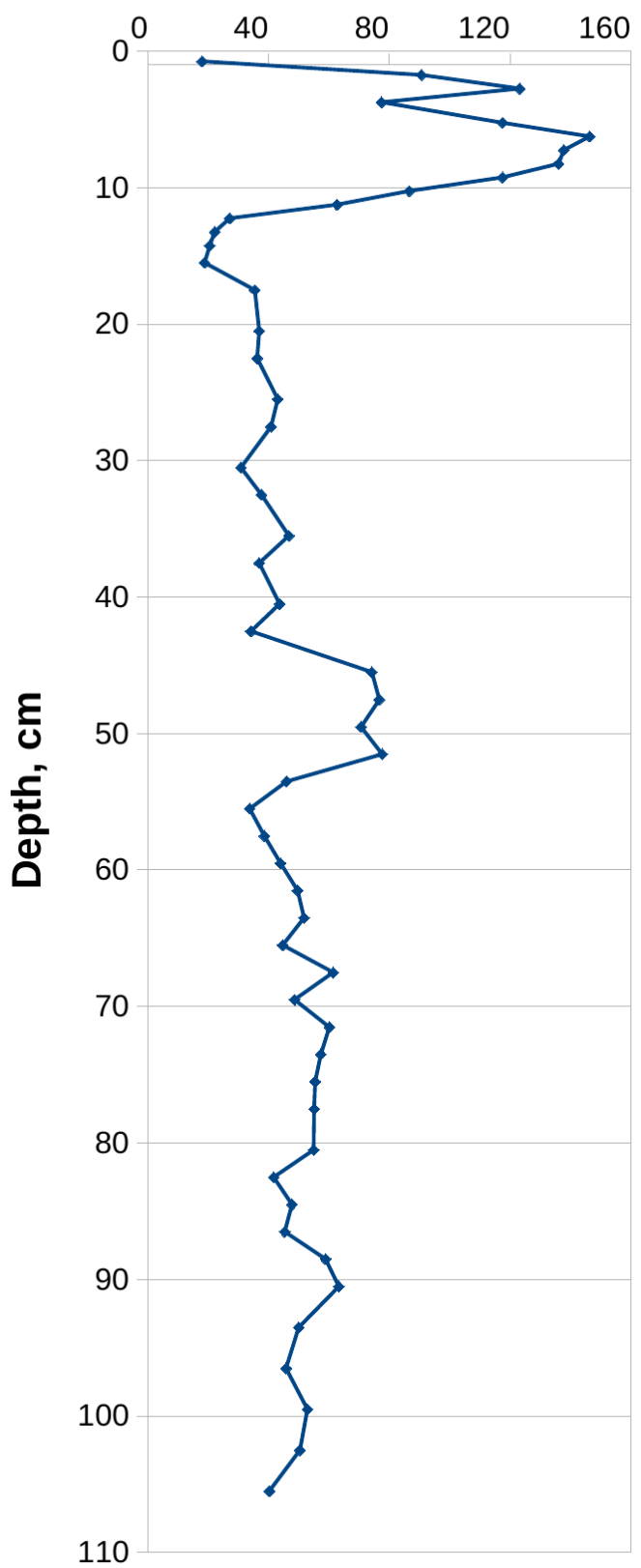

Fig. 6. Fe/Mn ratio in Wolbrom W3 core.

huge area of zinc and lead ores occurring (Nieć, 1997). Because of the winds from west, the region can be polluted by heavy metals (Kruczała, 2000). It is conspicuous that in case of almost every investigated element the concentration value is high in the upper part of the graph (between approximately 1850 and 1950 AD), which corresponds with the times of industrial revolution. Industrial effect is also visible in high concentration level of lead and copper in the mid-twentieth century. A rapid increase of lead, zinc and copper concentration starts in the time of the Roman Empire; however an increase of these metals concentration is visible from $3400 \mathrm{BC}$.

The presented results could be helpful for study of human impact on the environment. The obtained results, i.e. the age-depth model as well as the trace elements concentrations, can prove that in the Olkusz Ore-Bearing region mining and metallurgy industry had an impact over the centuries, starting at least in the $9^{\text {th }}$ century, which confirms former investigations (Chróst, 2013; Godzik and Woch, 2015; Magiera et al., 2016). The maximum of trace elements concentration occurs partially in a time period, for which the time scale is not precise (10$13 \mathrm{~cm}$ depth). It means that other explanations of this maximum are possible. Unfortunately, because of the hiatus, the reconstruction of information concerning the phenomena occurring in the period of Middle Ages and the beginning of modern metallurgy industry is not possible. Even so, these data could allow for historical reconstruction of metallurgy industry in earlier times but it needs further analyses. In this case, knowledge about the ratios of lead isotopes could be very valuable because it helps to determine the origin of metals. The ICP-MS measurements of ${ }^{204} \mathrm{~Pb},{ }^{206} \mathrm{~Pb},{ }^{207} \mathrm{~Pb}$ and ${ }^{208} \mathrm{~Pb}$ are currently in progress in frame of the cooperation between Silesian University of Technology (Gliwice, Poland) and University of Liége (Belgium).

\section{ACKNOWLEDGEMENTS}

The authors would like to thank to prof. Krzysztof Lipka for sharing his experience and for helpful discussion about fens and peat types.

F. P. and K. T. would like to acknowledge the grant LIDER/001/404/L-4/2013 from the National Centre for Research and Development in Poland which allowed ${ }^{14} \mathrm{C}$ dating.

The research leading to geochemical analysis results has received funding from the Polish-Norwegian Research Programme operated by the National Centre for Research and Development under the Norwegian Financial Mechanism 2009-2014 in the frame of Project IMPACT - Contract No Pol-Nor/199338/45/2013.

\section{REFERENCES}

Ali AA, Ghaleb B, Garneau M, Asnong H and Loisel J, 2008. Recent peat accumulation rates in minerothophic fens of the Bay James region, Eastern Canada, inferred by $210 \mathrm{~Pb}$ and $137 \mathrm{Cs}$ radiometric techniques. Applied Radiation and Isotopes 66(10): 1350-1358, DOI 10.1016/j.apradiso.2008.02.091.

Bojakowska I and Lech D, 2008. Zróżnicowanie zawartości pierwiastków śladowych w torfach występujących na obszarze Polski (The diversity of trace elements content in peat occuring in Poland). Zeszyty Naukowe Politechniki Śląkiej, Górnictwo: 285: 31-41 (in Polish).

Boyle JF, 2001. Inorganic geochemical methods in palaeolimnology. In: Last WM, Smol JP, eds., Tracking Environmental Change Using Lake Sediments 2: Physical and Geochemical Methods: 83-141. 
Bronk Ramsey C and Lee S, 2013. Recent and Planned Developments of the Program OxCal. Radiocarbon 55(2-3): 720-730, DOI: 10.2458/azu_js_rc.55.16215.

Chróst L, 2013. Ołowiowy ślad Wiślan odczytany z torfowisk obszaru kruszconośnego śląsko-małopolskiego (Lead trace of Vistulans tribe read from peat bogs of Silesian-Malopolska, metalliferous zone). In: Boroń P, ed.: Argenti fossores at alii. Znaczenie gospodarcze wschodniej czéści Górnego Ślaska i zachodnich krańców Matopolski w późnej fazie wczesnego średniowiecza [X-XII wiek] (The economic importance of the eastern part of Upper Silesia and western ends of Malopolska in the late phase of the early Middle Ages [X-XII century]), Chronicon, Wrocław: 175-186, ISBN 97883-935760-6-7 (in Polish)

De Vleeschouwer F, Gérard L, Goormaghtigh C, Mattielli N, Le Roux $\mathrm{G}$ and Fagel N, 2007. Atmospheric lead and heavy metal pollution records from a Belgian peat bog spanning the last two millennia: Human impact on a regional to global scale. The Science of the Total Environment 377: 282-295.

Godzik B and Woch MW, 2015. History of mining in the Olkusz region. In: Godzik B, ed., Natural and historical values of the Olkusz Ore-Bearing region. W. Szafer Institute of Botany, Polish Academy of Sciences, Kraków: 29-36.

Ilnicki P, 2002. Torfowiska i torf (Peatlands and peat). Wydawnictwo Akademii Rolniczej im. Augusta Cieszkowskiego, Poznań, ISBN 83-7160-243-X (in Polish).

Kac NJ, Kac SW and Skobiejewa E, 1977. Atlas rastitielnych ostatkow w torfach (Atlas of plant residues in peat). Nedra, Moskwa (in Russian).

Karczewska A and Kabała C, 2008. Metodyka analiz laboratoryjnych gleb i roślin (Methods of laboratory analysis of soils and plants). Instytut Gleboznawstwa i Ochrony Srodowiska Rolniczego, Akademia Rolnicza, Wrocław (in Polish).

Kondracki J, 2013. Geografia regionalna Polski (Regional geography of Poland). Wydawnictwo Naukowe PWN, Warszawa, ISBN 97883-01-16022-7 (in Polish).

Kruczała A, ed., 2000. Atlas klimatu województwa ślaskiego (Climate Atlas of the Silesia Province). Instytut Meteorologii i Gospodarki Wodnej, Katowice: 34, 57, 74, 83-85862-64-1 (in Polish).

Latałowa M, 1976. Pollen diagram of the Late-glacial and Holocene peat deposits from Wolbrom (S Poland). Acta Palaeobotanica 17 (1): 55-80 (in Polish).

Latałowa M and Nalepka D, 1987. A study of the Late-glacial and Holocene vegetational history of the Wolbrom area (SilesianCracovian Upland). Acta Palaeobotanica 27 (1): 75-115.

Lis J and Pasieczna A, 1995. Geochemical atlas of Upper Silesia 1:200 000. Państwowy Instytut Geologiczny, Warszawa.

Maciak F and Liwski S, 1996. Ćwiczenia z torfoznawstwa (Exercises in peat science). Wydawnictwo SGGW, Warszawa. ISBN: 83-0002968-0 (in Polish).

MacKenzie AB, Farmer JG and Sugden CL, 1997. Isotopic evidence of the relative retention and mobility of lead and radiocaesium in Scottish ombrotrophic peats. Science of the Total Environment 203: 115-127, DOI 10.1016/S0048-9697(97)00139-3.

Magiera T, Mendakiewicz M, Szuszkiewicz M, Jabłońska M and Chróst L, 2016. Technogenic magnetic particles in soils as evidence of historical mining and smelting activity: A case of the Brynica River Valley, Poland. Science of the Total Environment 566-567: 536-551, DOI 10.1016/j.scitotenv.2016.05.126.

Maksimow A, 1965. Torf i jego użytkowanie w rolnictwie (Peat and its use in agriculture). PWRiL, Warszawa (in Polish).

Martínez Cortizas A, 2016. Early atmospheric metal pollution provides evidence for Chalcolithic/Bronze Age mining and metallurgy in Southwestern Europe. Science of the Total Environment 545-546: 398-406, DOI 10.1016/j.scitotenv.2015.12.078.

Myślińska E, 2001. Grunty organiczne i laboratoryjne metody ich badania (Organic soils and the laboratory test methods). Wydawnictwo Naukowe PWN, Warszawa. ISBN: 8301134178 (in Polish).

Nieć M, 1997. Złoża rud cynku i ołowiu (Deposits of zinc and lead ores). In: Kicki J, ed., Surowce mineralne Polski. Surowce metaliczne: cynk, ołów (Mineral resources of Poland. Metallic resources: zinc, lead). Wydawnictwo Centrum PPGSMiE PAN, Kraków: 9-46. ISBN 83-86286-83-1 (in Polish).
Nriagu JO, 1996. A history of global metal pollution. Science 272(5259): 223, DOI 10.1126/science.272.5259.223.

Obidowicz A, 1976. Genesis and development of the peat-bog at Wolbrom (S Poland). Acta Palaeobotanica 17(1): 45-54 (in Polish).

Pawlyta J, Pazdur A, Rakowski A, Miller BF and Harkness DD, 1998. Commissioning of Quantulus ${ }^{\mathrm{TM}}$ liquid scintillation beta spectrometer for measuring ${ }^{14} \mathrm{C}$ and ${ }^{3} \mathrm{H}$ at natural abundance levels. Radiocarbon 40(1): 201-209.

Pawłowski D, Kowalewski G, Milecka K, Płóciennik M, Woszczyk M, Zieliński T, Okupny D, Włodarski W and Forysiak J, 2015. A reconstruction of the palaeohydrological conditions of a flood-plain: A multi-proxy study from the Grabia River valley mire, central Poland. Boreas 44(3): 543-562, DOI 10.1111/bor.12115.

Pawłowski D, Borówka RK, Kowalewski GA, Luoto TP, Milecka K, Nevalainen L, Okupny D, Tomkowiak J and Zieliński T, 2016. Late Weichselian and Holocene record of the paleoenvironmental changes in a small river valley in Central Poland. Quaternary Science Reviews 135: 24-40, DOI 10.1016/j.quascirev.2016.01.005.

Reimer PJ, Bard E, Bayliss A, Beck JW, Blackwell PG, Bronk Ramsey C, Buck CE, Cheng H, Edwards RL, Friedrich M, Grootes PM, Guilderson TP, Haflidason H, Hajdas I, Hatté C, Heaton TJ, Hoffmann DL, Hogg AG, Hughen KA, Kaiser KF, Kromer B, Manning SW, Niu M, Reimer RW, Richards DA, Scott EM, Southon JR, Staff RA, SM Turney C and van der Plicht J, 2013. IntCal13 and Marine13 radiocarbon age calibration curves 050,000 years cal BP, Radiocarbon 55(4): 1869-1887.

Shotyk W, 1996. Natural and anthropogenic enrichments of $\mathrm{As}, \mathrm{Cu}, \mathrm{Pb}$, $\mathrm{Sb}$ and $\mathrm{Zn}$ in ombrotrophic versus minerotrophic peat bog profiles, Jura Mountains, Switzerland. Water, Air and Soil Pollution 90: 375-405, DOI 10.1007/BF00282657.

Sikorski J and Bluszcz A, 2003. Testing applicability of ${ }^{210} \mathrm{~Pb}$ method to date sediments of human-made lake Kozłowa Góra. Geochronometria 22: 63-66.

Sikorski J and Bluszcz A, 2008. Application of $\alpha$ and $\gamma$ spectrometry in the ${ }^{210} \mathrm{~Pb}$ method to model sedimentation in artificial retention reservoir. Geochronometria 31: 65-75, DOI 10.2478/v10003-0080019-4.

Skripkin V and Kovaliukh N, 1998. Recent developments in the procedures used at the SSCER Laboratory for the routine preparation of lithium carbide. Radiocarbon 40(1): 211-214.

Śmieja-Król B, Janeczek J, Bauerek A and Thorseth IH, 2015. The role of authigenic sulfides in immobilization of potentially toxic metals in the Bagno Bory wetland, southern Poland. Environmental Science and Pollution Research 22(20): 15495-15505, DOI 10.1007/s11356-015-4728-8.

Theodórsson P, 2005. A simple, extremely stable single-tube liquid scintillation system for radiocarbon dating. Radiocarbon 47: 8997, DOI 10.2458/azu js rc.47.2803.

Tobolski K, 2000. Przewodnik do oznaczania torfów i osadów jeziornych (Guidebook for determination of peat and lake sediments). Wydawnictwo Naukowe PWN, Warszawa. ISBN 83-0113215-9 (in Polish).

Tołpa S, Jasnowski M and Pałczyński A, 1967. System der genetischen Klassifizierung der Torfe Mitteln-Europas. (System of the genetic classification of the peat in Central Europe). Zesz. Probl. Post. Nauk Rol. 76: 9-99 (in German).

Trela J, 1928. Torfowisko w Wolbromiu (wyniki analizy pyłkowej) (Peatland in Wolbrom /the results of pollen analysis/). Acta Soc. Bot. Pol. 5(3): 337-351.

Tudyka K, Bluszcz A, Kozłowska B, Pawlyta J and Michczyński A, 2015. Low level ${ }^{14} \mathrm{C}$ measurements in freshly prepared benzene samples with simultaneous 214Bi/214Po pairs counting for routine 222Rn contamination correction. Radiation Measurements 74: 611, DOI 10.1016/j.radmeas.2015.01.010.

Tudyka K and Pazdur A, 2012. ${ }^{14} \mathrm{C}$ Dating with the ICELS Liquid Scintillation Counting System Using Fixed-Energy Balance Counting Window Method. Radiocarbon 54: 267-273, DOI 10.2458/azu js rc.v54i2.15832.

Vile MA, Kelman Wieder R and Novák M, 1999. Mobility of $\mathrm{Pb}$ in Sphagnum-derived peat. Biogeochemistry 45: 35-52, DOI 10.1007/BF00992872. 